\title{
ANALISIS PENGARUH INSTRUMEN PEMBAYARAN NON- TUNAI TERHADAP STABILITAS SISTEM KEUANGAN DI INDONESIA
}

\author{
Nastiti Ninda Lintangsari ${ }^{1}$, Nisaulfathona Hidayati ${ }^{2}$, Yeni Purnamasari $^{3}$, Hilda Carolina ${ }^{4}$, \\ Wiangga Febranto \\ Diponegoro University \\ nastitininda@gmail.com
}

\begin{abstract}
The payment system is an important component in the economy especially to ensure the implementation of payment transactions made by the public and the business world. In addition, the payment system also plays an important role in supporting financial system stability and implementation of monetary policy. Along with rapid technological developments, patterns and payment systems in economic transactions are constantly changing. Technological advances in the payment instruments shift the role of cash as a means of payment in the form of more efficient and economical non-cash payments. Non-cash payment instruments used in this study are card-based payment instruments (APMK) and electronic money (e-money). The aim of this study is to examine the effect of non-cash payment instruments development on money supply (M1), velocity of money, inflation, interest rate, and financial system stability. A set of secondary data are assessed through official website of Bank Indonesia from year 2009-2017. Multiple regression analysis are employed to elaborate the results. The result showed that e-money and credit card transactions have a significant positive effect on M1, e-money transactions have a significant negative effect on interest rates, and credit card transactions have a significant positive effect on interest rates.
\end{abstract}

Keyword: financial system stability; e-money; debet card; credit card; non-cash payment instruments; $M$; interest rate; velocity of money

JEL classification: E41; E42; E43; E51; E52

\section{PENDAHULUAN}

Sistem pembayaran merupakan komponen penting dalam perekonomian terutama untuk menjamin terlaksananya transaksi pembayaran yang dilakukan masyarakat dan dunia usaha. Selain itu itu sistem pembayaran juga berperan penting dalam mendukung terciptanya stabilitas sistem keuangan dan pelaksanaan kebijakan moneter. Demi menjamin kelancaran dan keamanan sistem pembayaran, Bank Indonesia melakukan kebijakan yang berfokus pada empat aspek utama yaitu peningkatan keamanan, efisiensi, perluasan akses dalam sistem pembayaran dan memperhatikan perlindungan konsumen.

Peningkatan keamanan dalam sistem pembayaran bertujuan untuk menjaga kepercayaan masyarakat akan berbagai alternatif instrumen pembayaran yang dapat digunakan masyarakat dalam kegiatan ekonomi yang dilakukannya. Sementara itu peningkatan efisiensi melalui upaya interkoneksi sistem pembayaran menjadi sangat penting 
agar industri sistem pembayaran dapat melakukan sharing investasi pengembangan infrastruktur untuk menciptakan efisiensi secara nasional baik bagi industri sistem pembayaran maupun bagi masyarakat pengguna karena tidak harus memiliki banyak instrumen pembayaran dalam melakukan berbagai transaksi pembayaran. Dari sisi perluasan akses dalam sistem pembayaran, Bank Indonesia senantiasa mendorong industri sistem pembayaran untuk memperluas cakupan layanan sistem pembayaran sehingga dapat lebih luas dan merata ke seluruh wilayah Indonesia, tidak hanya di kota-kota besar. Selanjutnya, perlindungan konsumen merupakan faktor yang tidak kalah penting dalam penetapan kebijakan dan pengembangan sistem pembayaran untuk menempatkan posisi konsumen pengguna jasa sistem pembayaran setara dengan penyelenggara sistem pembayaran. Hal ini menjadi penting agar masyarakat sebagai konsumen pengguna jasa sistem pembayaran dapat semakin terlindungi dan tidak lagi berada pada posisi lemah yang diakibatkan dari kekurang pahaman masyarakat atas manfaat dan risiko dari suatu instrumen dan mekanisme pembayaran yang digunakan.

Seiring dengan perkembangan teknologi yang pesat, pola dan instrumen pembayaran dalam transaksi ekonomi terus mengalami perubahan. Kemajuan teknologi dalam instrumen pembayaran menggeser peranan uang tunai sebagai alat pembayaran ke dalam bentuk pembayaran non tunai yang lebih efisien dan ekonomis. Pembayaran non tunai umumnya dilakukan dengan cara mentransfer antar bank maupun transfer intra bank melalui jaringan internal bank sendiri. Selain itu pembayaran non tunai dilakukan dengan kartu sebagai alat pembayaran seperti kartu ATM, kartu debit dan kartu kredit.

Perkembangan non tunai dari tahun ke tahun mengalami peningkatan, selain didukung oleh kemajuan teknologi adanya perubahan pola hidup masyarakat dan berkembangnya inovasi menambah macam transaksi non tunai. Di jaman modern seperti saat ini, kepraktisan merupakan hal yang sangat penting. Untuk kebutuhan keuangan kini banyak sekali teknolgi yang dapat digunakan misalnya berkembangnya e-money. E-money memudahkan dan mendukung kebutuhan aktivitas manusia dalam banyak hal misalnya membayar tol, transaksi umum seperti membeli pulsa dan berbelanja. Berbeda dengan kartu ATM, kartu debit, dan kartu kredit yang terhubung langsung ke rekening pengguna, transaksi melalui e-money tidak terhubung dengan rekening pengguna melainkan memiliki kantong sendiri yang dapat diisi ulang dengan cara top-up.

Grafik 1. Volume dan Transaksi Alat Pembayaran Non Tunai (2009-2016)

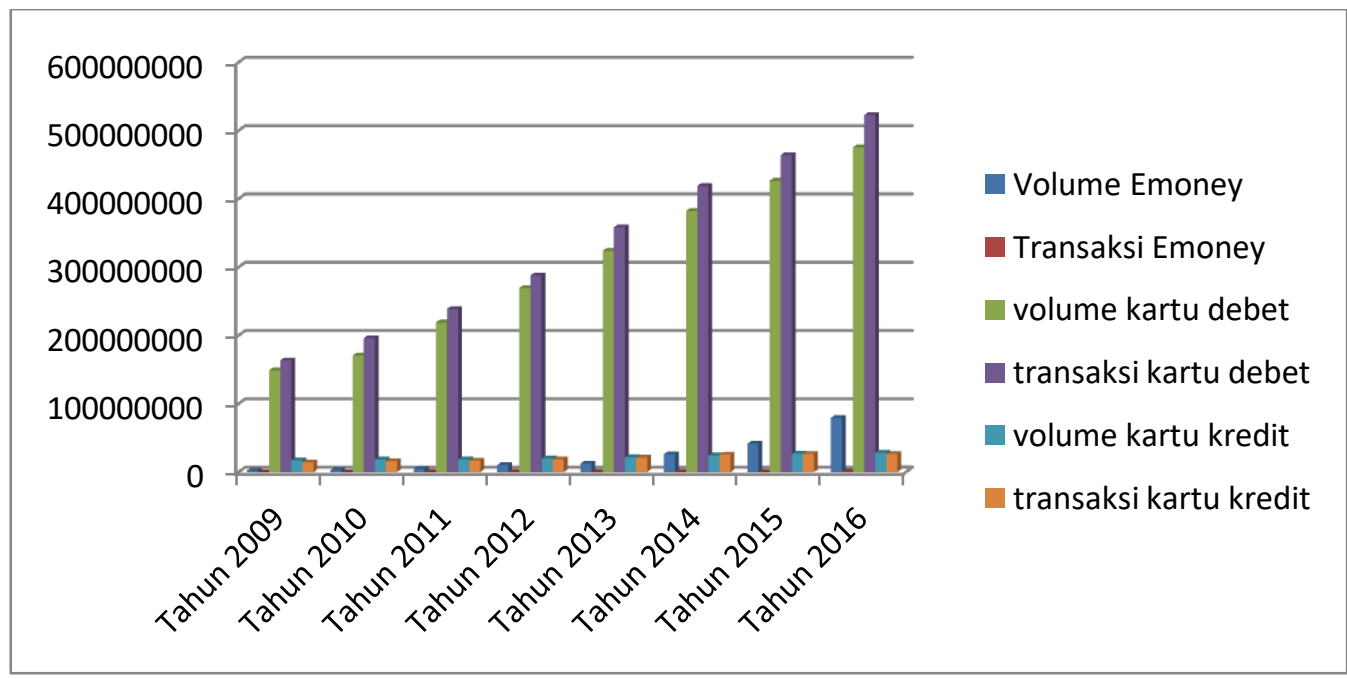

Sumber: Bank Indonesia (data diolah) 
Berdasarkan data di atas, menunjukkan bahwa dari 2009 sampai 2016 penggunaan instrumen pembayaran non tunai selalu mangalami peningkatan di setiap tahun yang mengindikasikan bahwa instrumen pembayaran non tunai sudah diterima oleh masyarakat sebagai bagian dari transaksi.

Bank Indonesia selaku otoritas moneter bertugas untuk menjaga stabilitas sistem keuangan. Indikator yang digunakan dalam menjaga stabilitas sistem keuangan dilakukan penetapan sasaran sasaran moneter seperti Jumlah uang beredar dan suku bunga. Kestabilan jumlah uang beredar dan suku bunga perlu mendapatkan dukungan dari sistem pembayaran. Hal ini berarti perkembangan sistem pembayaran non tunai perlu dikontrol dan diawasi agar tidak memberikan dampak yang buruk pada sasaran moneter.

\section{Tujuan Penelitian}

Berdasarkan latar belakang di atas, melihat semakin tingginya instrumen pembayaran non-tunai, penulis merumuskan tujuan penelitian sebagai berikut:

1. Untuk mengetahui pengaruh instrumen pembayaran non tunai terhadap jumlah uang beredar (M1) di Indonesia

2. Untuk mengetahui pengaruh instrumen pembayaran non tunai terhadap perputaran uang (velocity of money) di Indonesia

3. Untuk mengetahui pengaruh instrumen pembayaran non tunai terhadap tingkat suku bunga di Indonesia

4. Untuk mengetahui pengaruh instrumen pembayaran non tunai terhadap stabilitas sistem keuangan di Indonesia.

\section{TINJAUAN PUSTAKA}

\section{III.1 Instrumen Pembayaran Non Tunai}

Bank - bank sentral di dunia saat ini mendorong penggunaan instrumen pembayaran non tunai. Hal ini dikarenakan pembayaran non tunai relatif lebih aman, selain itu juga dapat meningkatkan efektifitas dan efisiensi sistem pembayaran karena transaksinya lebih murah, cepat, dan mudah sehingga dapat meningkatkan produktivitas perekonomian negara. Perkembangan sistem pembayaran ini didukung dengan adanya alat pembayaran dengan menggunakan kartu (APMK). Yang termasuk dalam APMK adalah aktivitas yang dalam proses pembayaran menggunakan kartu seperti, kartu ATM/debet dan kartu kredit. Transaksi pembayaran dengan menggunakan instrument APMK saat ini bersifat account based, sehingga setelmen transaksi dilakukan pada level bank dengan metode yang dipilih oleh masing - masing bank sesuai denga skala operasional jaringannya. 


\section{Grafik 2. Grafik Jumlah APMK yang Beredar}

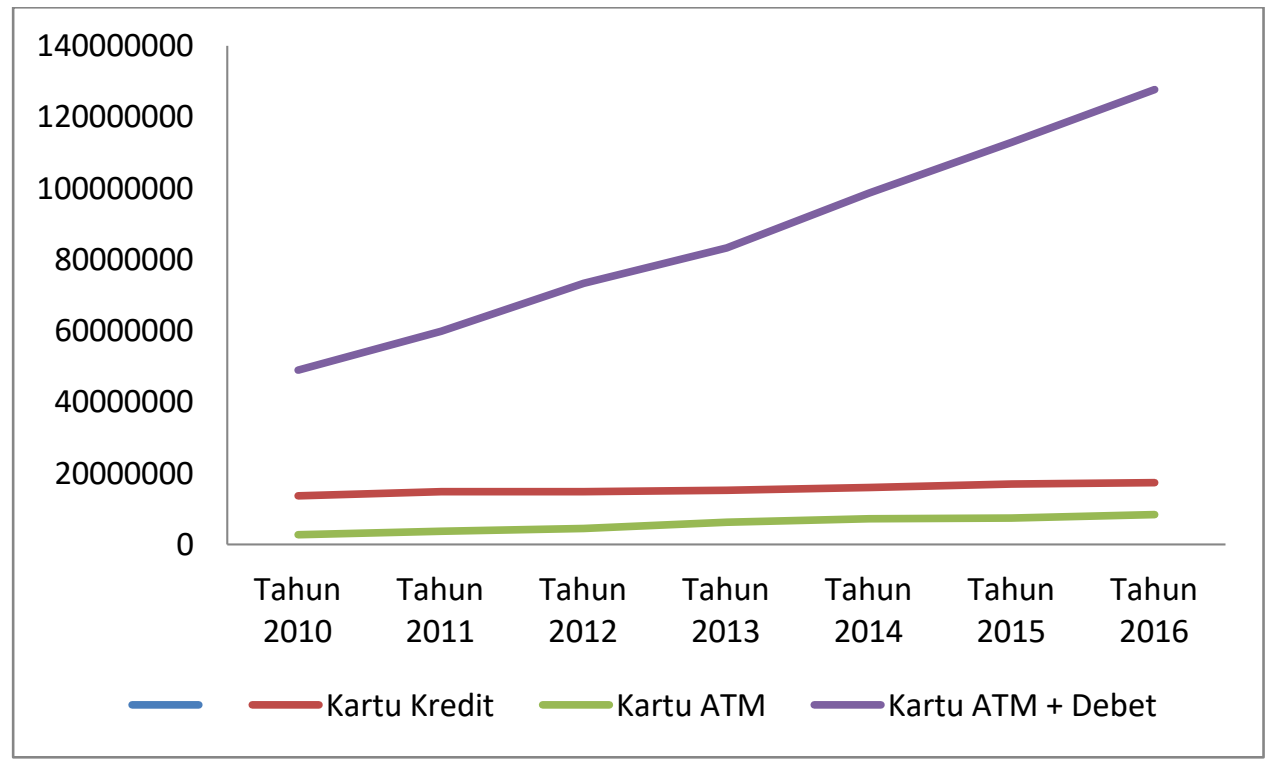

Sumber : Bank Indonesia (data diolah)

Jumlah pemegang APMK mengalami peningkatan dari waktu ke waktu. Perkembangan tersebut didukung oleh semakin beragamnya fasilitas/fungsi APMK. Saat ini cukup banyak variasi intrumen pembayaran non tunai, beberapa contoh yang cukup marak digunakan antara lain, Kartu ATM/debet, kartu kredit, dan uang elektronik (e-money). Dimana uang elektronik menurut PBI memiliki aturan dan definisi yang berbeda dengan alat pembayaran berbasis kartu lainnya, seperti kartu kredit dan kartu ATM/debet. Dimana kartu kredit dan kartu ATM/debet merupakan access product bukan prepaid product. Berikut merupakan perbedaan karakteristik antara access product dan prepaid product:

1. Access product (kartu ATM/debet dan kartu kredit)

- Tidak ada pencatatan dana pada instrumen kartu.

- Dana sepenuhnya berada dalam pengelolaan bank, sepanjang belum ada otorisasi dari nasabah untuk melakukan pembayaran.

- Pada saat transaksi, instrumen kartu digunakan untuk melakukan akses secara on-line ke komputer issuer untuk mendapatkan otorisasi melakukan pembayaran atas beban rekening nasabah, baik berupa rekening simpanan (kartu debet) maupun rekening pinjaman (kartu kredit). Setelah di-otorisasi oleh issuer, rekening nasabah kemudian akan langsung didebet. Dengan demikian pembayaran dengan menggunakan kartu kredit dan kartu debet mensyaratkan adanya komunikasi on-line ke komputer issuer.

2. Prepaid product (e-money)

- Nilai uang telah tercatat dalam instrumen e-money, atau sering disebut dengan stored value.

- Dana yang tercatat dalam e-money sepenuhnya berada dalam penguasaan konsumen.

- Pada saat transaksi, perpindahan dana dalam bentuk electronic value dari kartu e-money milik konsumen kepada terminal merchant dapat dilakukan secara off-line. Dalam hal ini verifikasi cukup dilakukan pada level merchant (point of sale), tanpa harus on-line ke computer issuer. 
Dalam perkembangan sistem pembayaran non tunai belum terdapat indikator yang pasti dalam pengukurannya. Pengukuran indikator perkembangan pembayaran non tunai pada berbagai studi (Markose dan Loke, 2000; BIS, 1999; dan RBA, 2003) umumnya menggunakan data perkembangan volume transaksi melalui alat pembayaran menggunakan kartu seperti ATM/debet dan kartu kredit. Selain itu, beberapa indikator rasio seperti rasio antara konsumsi swasta terhadap uang kartal di masyarakat dan rasio uang tunai terhadap M1 juga dapat digunakan sebagai indikator perkembangan pembayaran non tunai.

\section{III.2 Stabilitas Sistem Keuangan}

Stabilitas sistem keuangan hingga saat ini belum memiliki definisi yang baku secara internasional. Oleh karena itu, muncul beberapa definisi stabilitas sistem keuangan dari berbagai sumber, seperti berikut :

- Schinasi (2004) mendefinisikan stabilitas sistem keuangan secara umum sebagai kemampuan sistem keuangan untuk melakukan alokasi sumber dana dalam mendukung kegiatan ekonomi, mengelola risiko, dan bertahan dari gejolak.

- Norges Bank mendefinisikan stabilitas sistem keuangan sebagai kondisi dimana sektor keuangan sehat dan kuat dalam menghadapi gejolak pada institusi keuangan atau pasar keuangan.

- Nout Wellink (De Nederlandsche Bank), kemampuan sistem keuangan untuk mengalokasikan sumber dana, menghadapi gejolak, mencegah dampak buruk dari gejolak terhadap ekonmi riil sistem keuangan lainnya.

Menurut Bank Indonesia arti dari stabilitas sistem keuangan dapat dipahami dengan melakukan penelitian terhadap faktor- faktor yang dapat menyebabkan instabilitas di sektor keuangan. Ketidakstabilan sistem keuangan dapat dipicu oleh berbagai macam penyebab dan gejolak. Hal ini biasanya merupakan kombinasi antara kegagalan pasar, baik karena faktor struktural maupun perilaku. Kegagalan pasar itu bersumber dari eksternal (internasional) dan internal (domestik). Risiko yang sering menyertai kegiatan dalam sistem keuangan antara lain risiko kredit, risiko likuiditas, risiko pasar dan risiko operasional.

Sistem keuangan memegang peranan yang sangat penting dalam perekonomian. Sebagai bagian dari sistem perekonomian, sistem keuangan berfungsi mengalokasikan dana dari pihak yang mengalami surplus kepada yang mengalami defisit. Apabila sistem keuangan tidak stabil dan tidak berfungsi secara efisien, pengalokasian dana tidak akan berjalan dengan baik sehingga dapat menghambat pertumbuhan ekonomi. Sistem keuangan yang tidak stabil, mengakibatkan terjadinya krisis, dimana memerlukan biaya yang sangat tinggi untuk upaya penyelamatannya.

Bank Indonesia mengatakan bahwa ketidakstabilan sistem keuangan dapat mengakibatkan timbulnya beberapa kondisi yang tidak menguntungkan seperti:

- Transmisi kebijakan moneter tidak berfungsi secara normal sehingga kebijakan moneter menjadi tidak efektif.

- Fungsi intermediasi tidak dapat berjalan sebagaimana mestinya akibat alokasi dana yang tidak tepat sehingga menghambat pertumbuhan ekonomi.

- Ketidakpercayaan publik terhadap sistem keuangan yang umumnya akan diikuti dengan perilaku panik para investor untuk menarik dananya sehingga mendorong terjadinya kesulitan likuiditas.

Berdasarkan Warjiyo, Perry (2016) dalam Bauran Kebijakan Bank Sentral: Konsepsi Pokok dan Pengalaman Bank Indonesia menyebutkan bahwa kebijakan moneter mempengaruhi atau berdampak pada stabilitas sistem keuangan melalui suku bunga, nilai tukar, likuiditas, kredit perbankan, dan keputusan perusahaan. 


\section{III.2.1 Faktor yang Mempengaruhi Stabilitas Sistem Keuangan}

Secara umum faktor - faktor yang mempengaruhi stabilitas sistem keuangan terdapat dua macam yaitu, faktor endogen yang berasal dari dalam sistem keuangan itu sendiri, dan faktor eksogen yang berasal dari luar sistem keuangan tersebut. Faktor - faktor tersebut berhubungan membentuk siklus umpan balik pada masing - masing elemen di dalam sistem keuangan.

\section{Gambar 1. Faktor - faktor yang mempengaruhi SSK}

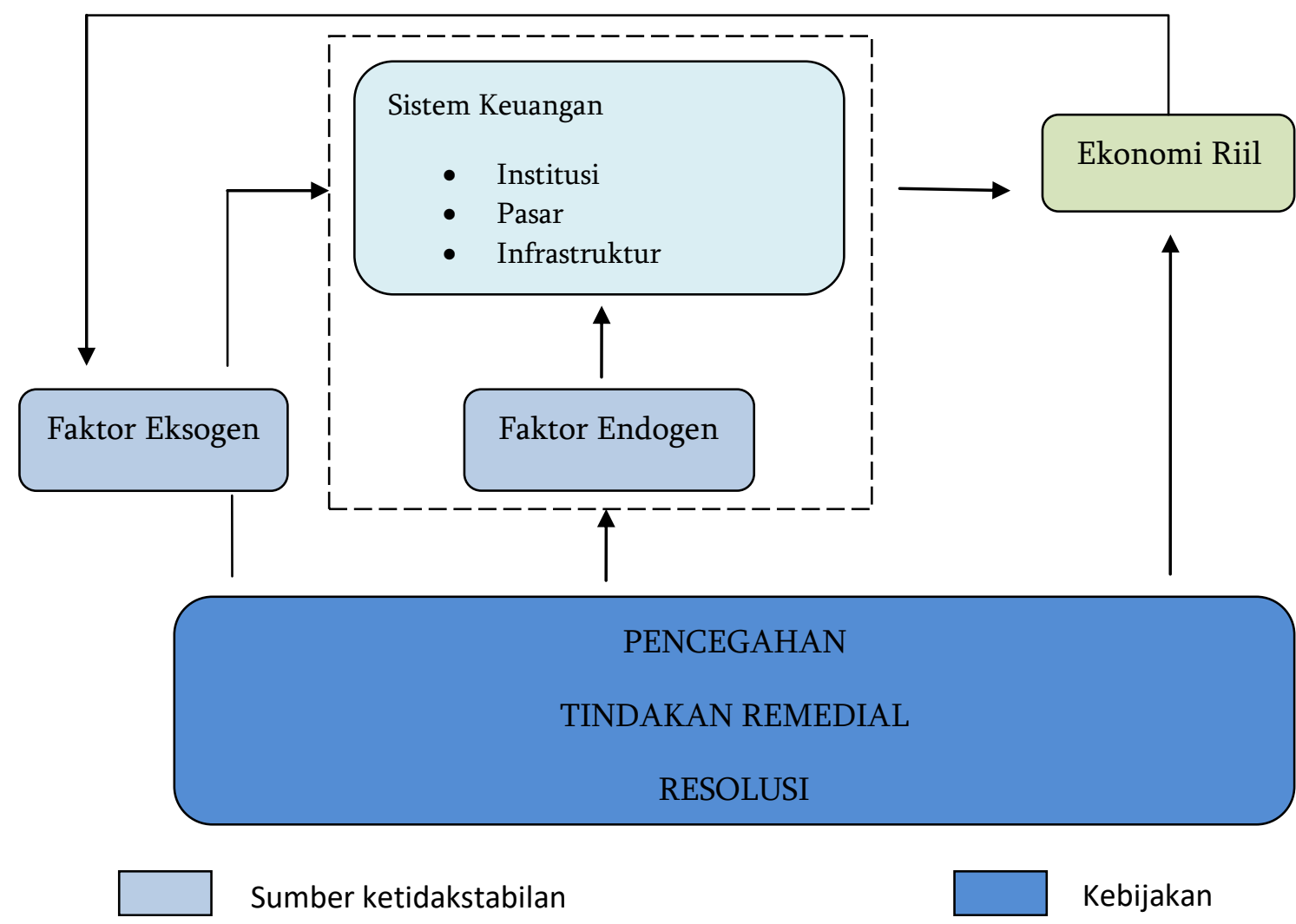

Sumber: Houben, Kaikes, and Schinasi, 2004 dalam Pengantar Kebansentralan oleh Iskandar Simorangkir

Faktor endogen dan faktor eksogen mempengaruhi kinerja sistem keuangan melalui institusi, pasar, maupun infrastruktur keuangan. Hasil kinerja sistem keuangan akan mempengaruhi kinerja ekonomi riil yang merupakan umpan balik dari faktor eksogen yang mempengaruhi sistem keuangan sehingga membentuk suatu siklus. Dan ketika gejolak tidak wajar muncul pada salah elemen akan mempengaruhi perjalanan siklus.

\section{III.3 Teori Permintaan Uang}

III.3.1 Teori Irving Fischer

Teori permintaan uang atau yang lebih dikenal dengan teori kuantitas uang yang digagas oleh tokoh klasik, Irving Fischer, dirumuskan sebagai berikut :

$$
\mathbf{M} \cdot \mathbf{V}=\mathbf{P} \cdot \mathbf{T}(\mathbf{1})
$$

Dengan M sebagai jumlah uang beredar, V sebagai velocity of money atau kecepatan pergerakan uang, $\mathrm{P}$ sebagai harga dan $\mathrm{T}$ sebagai jumlah transaksi yang terjadi didalam perekonomian. Pada teori ini dijelaskan bahwa perubahan jumlah uang beredar akan proporsional dengan perubahan harga, apabila $\mathrm{V}$ dan $\mathrm{T}$ diasumsikan konstan. 
Dalam makalah ini, jumlah uang beredar yang dimaksud adalah M1 yang terdiri dari uang kartal, uang giral, APMK dan e-money. Berdasarkan karakteristik APMK dan e-money yang dapat digunakan setiap saat sebagai alat pembayaran, maka jenis dana ini dikategorikan sebagai dana yang sangat likuid sehingga APMK dan e-money dapat disetarakan dengan uang kartal dan giral.

Menurut teori kuantitas uang, velocity of money dianggap konstan. Akan tetapi pada kenyataannya, velocity of money tidak konstan. Menurut Pramono, Bambang (2006) dalam working paper berjudul Dampak Pembayaran Non Tunai terhadap Perekonomian dan Kebijakan Moneter, velocity of money di Indonesia menunjukkan kecenderungan yang meningkat sebelum krisis, kemudian menurun ketika masa krisis dan meningkat kembali pasca krisis, khususnya sejak tahun 2002, yang diiringi dengan perbaikan kondisi ekonomi. Peningkatan kembali velocity of money ini mengindikasikan peningkatan peranan alat pembayaran non tunai dalam menggantikan uang tunai pada kegiatan ekonomi. Peningkatan tersebut dapat terjadi karena alat pembayaran non tunai belum dimasukkan dalam perhitungan variabel jumlah uang beredar.

Mengacu pada teori kuantitas uang, inflasi merupakan proksi dari harga (P), dimana perubahannya proporsional dengan perubahan jumlah uang beredar (M), ceteris paribus. Apabila JUB terlalu banyak beredar maka akan memicu kenaikan harga dan kenaikan harga yang terjadi secara terus menerus akan berpotensi menyebabkan inflasi. Inflasi yang terus meningkat hingga tidak mampu dikontrol oleh otoritas moneter akan mengganggu stabilitas sistem keuangan.

\section{III.3.2 Teori Keynes}

Keynes menyatakan bahwa pertimbangan seseorang dalam memegang uang dipengaruhi oleh 3 motif yang mendasarinya, yaitu motif untuk transaksi, motif untuk berjaga-jaga dan motif untuk spekulasi.

a) Motif transaksi

$$
\mathbf{M}(\mathbf{Y})=\mathbf{a}+\mathbf{b Y} ; \mathbf{b}>\mathbf{0} ; \text { transaksi }(2)
$$

Apabila penerimaan dan pengeluaran yang dilakukan oleh seseorang memiliki jumlah dan dimensi waktu yang sama, maka individu tersebut tidak memerlukan uang dalam transaksi-transaksinya. Akan tetapi dalam kenyataannya, jumlah dan dimensi waktu antara penerimaan dan pengeluaran berbeda sehingga uang diperlukan untuk memperlancar jalannya transaksi-transaksi yang dilakukan. Volume transaksi yang dilakukan bergantung pada pendapatan. Semakin besar pendapatan, volume transaksi juga akan semakin besar.

\section{b) Motif berjaga-jaga}

Adanya pengeluaran-pengeluaran yang tidak direncanakan menjadi alasan bagi seseorang untuk memegang uang dengan motif berjaga-jaga. Motif ini seringkali digunakan pada keperluan-keperluan yang bersifat mendadak dan tidak terduga seperti biaya pengobatan saat sakit dan giro wajib minimum yang disimpan di bank sentral sebagai bentuk kebijakan countercyclical buffer.

Besarnya uang yang diperlukan untuk berjaga-jaga pada umumnya tergantung besar kecilnya transaksi yang diadakan. Oleh karena itu, kebutuhan uang untuk 
berjaga-jaga sering dijadikan satu dengan kebutuhan untuk transaksi oleh para pemikir ekonomi.

c) Motif spekulasi

Fungsi uang selain untuk memperlancar transaksi dan berjaga-jaga, menurut Keynes, uang juga dapat sebagai motif spekulasi. Maksud spekulasi ini adalah spekulasi pada surat-surat berharga, khususnya surat obligasi.

Ketika suku bunga meningkat, maka harga obligasi akan turun dan permintaan jumlah uang beredar akan rendah. Sebaliknya ketika suku bunga turun, harga obligasi akan meningkat dan permintaan jumlah uang beredar untuk maksud spekulasi akan meningkat (Reksoprayitno, Soediyono, 2000).

Suku bunga merupakan salah satu indikator stabilitas sistem keuangan. Naik turunnya suku bunga akan mempengaruhi jumlah uang beredar di masyarakat. Dengan begitu, naik turunnya BI rate akan mempengaruhi keputusan masyarakat terhadap permintaan M1 yang terdiri dari uang kartal, uang giral dan pembayaran non tunai.

\section{METODE PENELITIAN}

\section{IV.1 Metodologi Penelitian}

Pada penelitian ini, penulis menggunakan metode penelitian regresi berganda untuk setiap variabel yang digunakan. Analisis regresi linear berganda adalah analisis yang dipergunakan untuk mengetahui pengaruh antara lebih dari satu variabel bebas terhadap satu buah variabel terikat. Analisis regresi linear berganda dilakukan menggunakan program aplikasi E-Views 9. Aplikasi E-Views merupakan program komputer berbasis Windows yang banyak dipakai untuk analisis statistika dan ekonometri jenis runtun-waktu (time series).

Metode penelitian yang dilakukan pertama yaitu meregresikan seluruh variabel independennya yaitu ATM, ATM dan debit, kartu kredit, volume $e$-money dan transaksi $e$ money dengan dependen M1. Hal ini bertujuan untuk melihat manakah variabel independen tersebut yang berpengaruh signifikan terhadap M1. Kedua, meregresikan seluruh variabel independen yang sama dengan dependen perputaran uang (velocity of money). Data perputaran uang diambil dengan cara membagi GDP riil dengan M1. Ketiga, meregresikan seluruh variabel independen yang sama dengan dependen inflasi. Terakhir, meregresikan variabel independen yang sama dengan dependen tingkat suku bunga.

Dari hasil regresi seluruh variabel independen terhadap variabel dependen tersebut, kemudian dianalisis bagaimana dampaknya terhadap stabilitas sistem keuangan. Hal ini dilakukan dengan asumsi bahwa M1, velocity of money, tingkat suku bunga, dan inflasi merupakan beberapa indikator Bank Indonesia selaku otoritas moneter untuk mengendalikan stabilitas moneter dalam rangka menjaga stabilitas sistem keuangan.

\section{IV.2 Data Penelitian}

Variabel yang digunakan dalam penelitian ini dibagi menjadi dua yaitu variabel dependen dan independen. Variabel dependen adalah variabel yang memberikan reaksi/respons jika dihubungkan dengan variabel independen. Pada penelitian ini, variabel dependen yang digunakan adalah M1, perputaran uang, inflasi, dan tingkat suku bunga. 
Sedangkan variabel independen adalah variabel stimulus atau variabel yang memengaruhi variabel lain. Pada penelitian ini, variabel independen yang digunakan adalah Alat Pembayaran Non Tunai yaitu Alat Pembayaran Menggunakan Kartu (APMK) seperti ATM, kartu debit, dan kartu kredit dan Uang Elektronik.

Jenis data pada penelitian ini merupakan jenis data sekunder. Data sekunder merupakan data yang diperoleh secara tidak langsung serta menjadi data pendukung dalam suatu penelitian. Penelitian ini menggunakan data kuartalan dari tahun 2009-2017, namun untuk tahun 2017 hanya berbatas sampai kuartal ke-2. Data tingkat suku bunga diambil dengan menggunakan data BI rate untuk tahun 2009-2015 dan menggunakan data BI 7 Days Repo untuk tahun 2016-2017. Data diambil dari website resmi Bank Indonesia (http://www.bi.go.id).

\section{HASIL DAN PEMBAHASAN}

\section{V.1 Pengaruh Instrumen Pembayaran Non Tunai terhadap Jumlah Uang Beredar (M1)}

Tabel 1. Pengaruh Instrumen Pembayaran Non Tunai terhadap M1

\begin{tabular}{lccc|}
\hline & $\beta$ & t-statistik & Prob \\
\hline (Constant) & 276969.2 & $5.98 * * *$ & 0.00 \\
TEM & 0.185457 & $2.21 * *$ & 0.03 \\
TKD & 0.001533 & $5.05 * * *$ & 0.00 \\
TKK & 0.000936 & 0.16 & 0.87 \\
\hline $\mathrm{F}$ & 391.6 & 0.00 \\
$\mathrm{R}^{2}$ & 0.97 & \\
*Signifikan secara statistik pada tingkat 0,10 & \\
$* *$ Signifikan secara statistik pada tingkat 0,05 & \\
$* * *$ Signifikan secara statistik pada tingkat 0,01 &
\end{tabular}

Dari hasil analisis, pengaruh sistem pembayaran non tunai terhadap jumlah uang beredar (M1) dihasilkan persamaan sebagai berikut.

$$
\mathrm{M} 1=276969.2+0.185457 \mathrm{TEM}(* *)+0.001533 \mathrm{TKD}(* * *)+0.000936 \mathrm{TKK}
$$

- Transaksi e-money berpengaruh positif dan signifikan secara statistik pada tingkat 0,05 (tingkat kepercayaan 95\%) terhadap M1. Setiap kenaikan transaksi e-money sebesar 1 juta akan meningkatkan jumlah uang beredar (M1) sebesar 0,185457 juta.

- Transaksi kartu debet berpengaruh positif dan signifikan secara statistik pada tingkat 0,01 (tingkat kepercayaan 99\%) positif pula terhadap M1. Setiap kenaikan transaksi kartu debet sebesar 1 juta akan meningkatkan M1 sebesar 0,001533 juta.

- Transaksi kartu kredit, tidak berpengaruh signifikan terhadap M1.

R-square dari analisis regresi persamaan ini sebesar 0,97 atau dapat diartikan bahwa variabel independen dapat menjelaskan variabel dependen sebesar 97\%, sedangkan sebesar 3\% dijelaskan oleh variabel lain yang tidak masuk dalam model. Variabel-variabel independen secara keseluruhan dengan melakukan uji $\mathrm{F}$ menunjukkan hasil yang signifikan terhadap variabel dependennya. Hal ini berarti variabel independen transaksi e-money, transaksi kartu debet, dan transaksi kartu kredit secara bersama-sama berpengaruh signifikan terhadap M1. 
Berpengaruhnya transaksi e-money, transaksi kartu debit, dan transaksi kartu kredit terhadap M1 sejalan dengan working paper Pramono, Bambang, dkk (2006) bahwa perkembangan alat pembayaran non tunai seperti kartu debet dengan tabungan sebagai underlyingnya menyebabkan terjadinya pergeseran fungsi tabungan dari simpanan yang tidak dapat ditarik sewaktu-waktu menjadi simpanan yang dapat ditarik sewaktu-waktu. Memperhatikan degree of moneyness dari jenis simpanan tabungan di atas, perlu diperhatikan pengklasifikasian tabungan yang menggunakan kartu debet sebagai bagian dari narrow money (M1) dalam kategori uang giral bukan lagi M2. (Pramono, Bambang, dkk, 2006)

Sedangkan pengaruh e-money terhadap M1 yang signifikan juga mendukung Pramono, Bambang, dkk (2006) bahwa dalam e-money terdapat istilah float yang berarti sejumlah dana yang dimiliki issuer dan tercatat dalam kartu e-money yang belum atau sudah digunakan untuk pembayaran namun belum ditagihkan oleh merchant. Mempertimbangkan karakteristik e-money yang memiliki float dana yang setiap saat dapat digunakan sebagai alat pembayaran, maka jenis dana ini dapat dikategorikan sebagai dana yang sangat likuid atau dapat disetarakan dengan uang tunai (cash) atau giro sehingga dapat dikategorikan sebagai bagian dari M1. Dalam Monetary and Financial Statistics (MFSM) 2000, paragraph 128, secara implisit dikatakan bahwa e-money dapat dikategorikan sebagai transferable deposits.

"Transferable deposits comprise all deposits that are (1) exchangeable on demand at par and without penalty or restriction and (2) directly usable for making payments by check, draft, giro order, direct debit/card, or other direct payment facility”

Berdasarkan definisi tersebut, perhitungan M1 di dalam statistik uang beredar, terkait penerbitan e-money akan menjadi:

$$
\mathrm{M1}=\mathrm{COB}+\mathrm{D}+\text { Float }(3)
$$

Sehingga, e-money merupakan komponen M1 dan dapat berpengaruh terhadap jumlah uang beredar sempit. (Hidayati, Siti,dkk, 2006)

\section{V.2 Pengaruh Instrumen Pembayaran Non Tunai terhadap Perputaran Uang (V)}

Tabel 2. Pengaruh Instrumen Pembayaran Non Tunai terhadap V

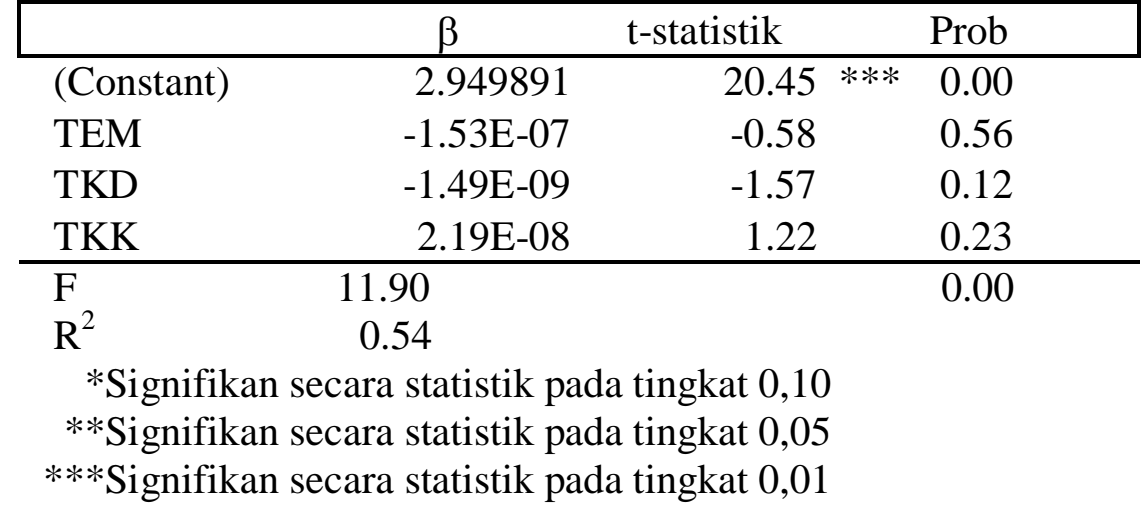

Dari hasil analisis, pengaruh sistem pembayaran non tunai terhadap perputaran uang (V) dihasilkan persamaan sebagai berikut.

$$
\mathrm{V}=2,949891-0,0000000153 \text { TEM - 0,000000149 TKD + 0,000000219 TKK }
$$


- Transaksi e-money, transaksi kartu debet, dan transaksi kartu kredit tidak berpengaruh signifikan terhadap perputaran uang.

R-square dari analisis regresi persamaan ini sebesar 0,54 atau dapat diartikan bahwa variabel independen dapat menjelaskan variabel dependen sebesar 54\%. Variabel-variabel independen secara keseluruhan dengan melakukan uji $\mathrm{F}$ menunjukkan hasil yang signifikan terhadap variabel dependennya. Hal ini berarti variabel independen transaksi e-money, transaksi kartu debet, dan transaksi kartu kredit secara bersama-sama berpengaruh signifikan terhadap perputaran uang.

Pengaruh instrumen pembayaran non-tunai terhadap perputaran uang dilihat dari pendekatan Real Money Balances Approach dapat mendukung hasil statistik tersebut. Dalam Kajian Hidayati, Siti, dkk (2006) pada pendekatan Real Money Balances Approach, penerbitan e-money diasumsikan sebagai salah satu faktor yang dapat merubah fungsi permintaan uang, yang selanjutnya dapat menurunkan jumlah rata-rata uang tunai yang dipegang oleh masyarakat dan akan menurunkan parameter $\mathrm{k}$, ceteris paribus.

$$
\begin{aligned}
& \left(\frac{M}{P}\right)^{d}=\mathrm{k} . \mathrm{Y} \\
& \left(\frac{M}{P}\right)=k . Y \\
& M \cdot\left(\frac{1}{k}\right)=P . Y \\
& M . V=P . Y \\
& V=\frac{Y}{\left(\frac{M}{P}\right)} \\
& \frac{1}{k}=\frac{Y}{\left(\frac{M}{P}\right)}
\end{aligned}
$$

Selanjutnya pada persamaan terakhir dapat dilihat bahwa penurunan average money holdings, ceteris paribus akan menurunkan parameter $\mathrm{k}$, yang berarti akan meningkatkan velocity of money (Siti Hidayati, 2006). Berarti, hubungan antar variabel e-money dan kartu debet terhadap velocity of money yaitu negatif sejalan dengan kajian Siti Hidayati, 2006 dimana dalam penelitian ini didapatkan hasil ketika transaksi e-money dan kartu debet di

\begin{tabular}{|c|c|c|c|c|}
\hline & $\beta$ & t-statistik & & Prob \\
\hline (Constant) & 4.211459 & 4.89 & $* * *$ & 0.00 \\
\hline TEM & $-3.46 \mathrm{E}-06$ & -2.22 & $* *$ & 0.03 \\
\hline
\end{tabular}
masyarakat meningkat maka velocity of money menurun meskipun tidak berpengaruh secara signifikan untuk masing-masing variabel. Sedangkan secara keseluruhan berpengaruh secara signifikan.

\section{V.3 Pengaruh Instrumen Pembayaran Non Tunai terhadap Tingkat Suku Bunga (r)}

Tabel 3. Pengaruh Instrumen Pembayaran Non Tunai terhadap r 


\begin{tabular}{llll}
$-\mathrm{TKD}$ & $-3.82 \mathrm{E}-09$ & -0.67 & 0.50 \\
$\mathrm{TKK}$ & $2.36 \mathrm{E}-07$ & $2.20 * *$ & 0.03 \\
\hline $\mathrm{F}$ & 6.38 & & 0.00 \\
$\mathrm{R}^{2}$ & 0.38 & &
\end{tabular}

*Signifikan secara statistik pada tingkat 0,10

**Signifikan secara statistik pada tingkat 0,05

***Signifikan secara statistik pada tingkat 0,01

Dari hasil analisis, pengaruh sistem pembayaran non tunai terhadap tingkat suku bunga (r) dihasilkan persamaan sebagai berikut.

$$
\mathrm{r}=4,211459-0,0000034 \mathrm{TEM}(* *)-0,0000038 \mathrm{TKD}+0,0000023 \mathrm{TKK}(* *)
$$

- Transaksi e-money berpengaruh negatif dan signifikan secara statistik pada tingkat 0,05 (tingkat kepercayaan 95\%) terhadap tingkat suku bunga. Setiap kenaikan transaksi e-money sebesar 1 juta akan menurunkan tingkat suku bunga sebesar 0,0000034\%.

- Transaksi kartu debet tidak berpengaruh signifikan terhadap suku bunga. Berbeda halnya dengan transaksi kartu kredit.

- Transaksi kartu kredit berpengaruh positif dan signifikan secara statistik pada tingkat 0,05 (tingkat kepercayaan 95\%) terhadap tingkat suku bunga. Setiap kenaikan transaksi kartu kredit sebesar 1 juta akan meningkatkan tingkat suku bunga sebesar 0,00000023\%.

R-square dari analisis regresi persamaan ini sebesar 0,38 atau dapat diartikan bahwa variabel independen dapat menjelaskan variabel dependen sebesar 38\%. Variabel-variabel independen secara keseluruhan dengan melakukan uji $\mathrm{F}$ menunjukkan hasil yang signifikan terhadap variabel dependennya. Hal ini berarti variabel independen transaksi e-money, transaksi kartu debet, dan transaksi kartu kredit secara bersama-sama berpengaruh signifikan terhadap tingkat suku bunga.

\section{V.4 Pengaruh Instrumen Pembayaran Non Tunai terhadap Inflasi}

Tabel 4. Pengaruh Instrumen Pembayaran Non Tunai terhadap INF

\begin{tabular}{lrrr|}
\hline & $\beta$ & t-statistik & Prob \\
\hline (Constant) & 2.870244 & 1.46 & 0.15 \\
TEM & $-5.64 \mathrm{E}-06$ & -1.59 & 0.12 \\
TKD & $6.04 \mathrm{E}-09$ & 0.46 & 0.64 \\
TKK & $1.09 \mathrm{E}-07$ & 0.44 & 0.65 \\
\hline $\mathrm{F}$ & & 0.28 \\
$\mathrm{R}^{2}$ & 1.31 & \\
*Signifikan secara statistik pada tingkat 0,10 & \\
$* *$ Signifikan secara statistik pada tingkat 0,05 & \\
$* * *$ Signifikan secara statistik pada tingkat 0,01 &
\end{tabular}

Dari hasil analisis, pengaruh sistem pembayaran non tunai terhadap inflasi (P) dihasilkan persamaan sebagai berikut.

$$
\mathrm{INF}=2,870244-0,0000056 \mathrm{TEM}+0,000000006 \mathrm{TKD}+0,0000001 \mathrm{TKK}
$$


- Transaksi e-money, transaksi kartu debet, dan transaksi kartu kredit tidak berpengaruh signifikan terhadap inflasi

$\mathrm{R}$-square dari analisis regresi persamaan ini sebesar 0,11 atau dapat diartikan bahwa variabel independen dapat menjelaskan variabel dependen sebesar $11 \%$. Variabel-variabel independen secara keseluruhan dengan melakukan uji $\mathrm{F}$ menunjukkan hasil yang tidak signifikan terhadap variabel dependennya. Hal ini berarti variabel independen transaksi $e$ money, transaksi kartu debet, dan transaksi kartu kredit secara bersama-sama tidak berpengaruh signifikan terhadap inflasi.

\section{V.5 Pengaruh Instrumen Pembayaran Non Tunai terhadap Stabilitas Sistem Keuangan}

Tabel 5. Pengaruh variabel independen terhadap dependan

\begin{tabular}{|c|c|c|}
\hline No & Variabel Independen & \multicolumn{1}{c|}{ Variabel Dependan } \\
\hline 1 & Transaksi E-money & $\begin{array}{r}\text { Berpengaruh signifikan: } \\
+ \text { Jumlah Uang Beredar (M1) } \\
-\quad \text { Tingkat Suku Bunga (r) }\end{array}$ \\
\hline 2 & Transaksi Kartu Debet & $\begin{array}{l}\text { Berpengaruh signifikan: } \\
+ \text { Jumlah Uang Beredar (M1) }\end{array}$ \\
\hline 3 & Transaksi Kartu Kredit & $\begin{array}{l}\text { Berpengaruh signifikan: } \\
+ \text { Tingkat Suku Bunga (r) }\end{array}$ \\
\hline
\end{tabular}

Pengaruh sistem pembayaran non tunai terhadap stabilitas sistem keuangan dapat dilihat dari pengaruh variabel independen terhadap variabel dependen yang berpengaruh signifikan. Dari hasil analisis, transaksi e-money dan transaksi kartu debet berpengaruh positif terhadap jumlah uang beredar. Apabila jumlah uang beredar di masyarakat meningkat secara terus menerus, maka akan berdampak pada inflasi. Hal ini akan berdampak pada stabilitas moneter. Pada hasil di atas walaupun variabel inflasi tidak dipengaruhi secara langsung oleh variabel independen yang ada namun tetap akan berdampak secara tidak langsung melalui peningkatan jumlah uang beredar.

Transaksi e-money berpengaruh negatif terhadap tingkat suku bunga yang dalam penelitian ini menggunakan BI rate dan BI 7 days repo sebagai suku bunga acuan yang dapat mempengaruhi transmisi pada suku bunga tabungan dan suku bunga kredit. Hal ini berarti apabila masyarakat terus meningkatkan transaksi melalui e-money, akan berdampak pada penurunan tingkat suku bunga. Tingkat suku bunga tabungan yang rendah akan membuat masyarakat lebih ingin memegang uang untuk transaksi sehingga jumlah uang beredar meningkat dan akan berdampak pada inflasi kembali. Sehingga pengaruh transaksi $e$-money terhadap tingkat suku bunga juga akan berdampak pada JUB dan inflasi secara tidak langsung. Tingkat suku bunga kredit yang rendah akibat kenaikan transaksi e-money akan membuat masyarakat lebih tertarik untuk melakukan kredit yang akan menimbulkan resiko apabila masyarakat tidak dapat melakukan pengembalian atas kredit tersebut sehingga nantinya akan berdampak pada ketidakstabilan sistem keuangan. Fenomena ini dapat dilihat pada Great Moderation tahun 2008 yang terjadi di Amerika Serikat dan menyebabkan krisis keuangan global 2008/2009 akibat rendahnya suku bunga sehingga kredit perumahan rakyat dengan tingkat bunga rendah sangat marak dan disekuritisasi dan diperdagangkan dalam sistem keuangan. Keterkaitan makrofinansial pada boom ekonomi tersebut meningkatkan resiko sistemik dan berujung pada krisis finansial yang besar dan berdampak ke seluruh dunia. (Perry Warjiyo, 2016) 
Berbeda halnya dengan transaksi kartu kredit yang berpengaruh positif terhadap tingkat suku bunga. Kenaikan tingkat suku bunga diindikasikan akibat naiknya transaksi kartu kredit. Apabila tingkat suku bunga tabungan naik, masyarakat akan lebih memilih untuk menabung di bank. Hal ini mengakibatkan bank lebih banyak menghimpun dana dari masyarakat sehingga jumlah uang beredar di masyarakat akan turun. Dampak buruk yang bisa terjadi apabila jumlah uang beredar di masyarakat terlalu sedikit akan mengakibatkan perekonomian yang lesu dikarenakan menurunnya konsumsi masyarakat turun sehingga pendapatan nasional akan turun.

Sedangkan di sisi lain, tingkat suku bunga kredit juga ikut naik. Masyarakat yang memiliki kartu kredit akan mengalami resiko default yaitu nasabah tidak menyelesaikan tagihan, sehingga akan mengakibatkan kegagalan sistem pembayaran. Kegagalan sistem pembayaran tentunya akan berdampak pada ketidakstabilan sistem keuangan. (Pramono Bambang, 2006).

\section{KESIMPULAN}

\section{VI.1 Kesimpulan}

Seiring berkembangnya teknologi, instrumen pembayaran pun berkembang dari sebelumnya tunai menjadi non-tunai. Dalam penelitian ini, penulis ingin mengetahui pengaruh instrumen pembayaran non-tunai terhadap stabilitas sistem keuangan yang diukur dari M1, velocity of money, inflasi, dan suku bunga. Instrumen pembayaran non-tunai yang digunakan dalam penelitian ini adalah kartu debet, kartu kredit, dan e-money. Berdasarkan hasil analisis di atas, didapatkan kesimpulan sebagai berikut:

a. Pengaruh instrumen pembayaran non-tunai terhadap M1

- Transaksi e-money berpengaruh positif dan signifikan secara statistik pada tingkat 0,05 (tingkat kepercayaan 95\%) terhadap M1. Setiap kenaikan transaksi e-money sebesar 1 juta akan meningkatkan jumlah uang beredar (M1) sebesar 0,185457 juta.

- Transaksi kartu debet berpengaruh positif dan signifikan secara statistik pada tingkat 0,01 (tingkat kepercayaan 99\%) positif pula terhadap M1. Setiap kenaikan transaksi kartu debet sebesar 1 juta akan meningkatkan M1 sebesar 0,001533 juta.

- Transaksi kartu kredit, tidak berpengaruh signifikan terhadap M1.

b. Pengaruh instrumen pembayaran non-tunai terhadap velocity of money

- Transaksi e-money, transaksi kartu debet, dan transaksi kartu kredit tidak berpengaruh signifikan terhadap perputaran uang.

c. Pengaruh instrumen pembayaran non-tunai terhadap suku bunga

- Transaksi e-money berpengaruh negatif dan signifikan secara statistik pada tingkat 0,05 (tingkat kepercayaan 95\%) terhadap tingkat suku bunga. Setiap kenaikan transaksi e-money sebesar 1 juta akan menurunkan tingkat suku bunga sebesar $0,0000034 \%$.

- Transaksi kartu debet tidak berpengaruh signifikan terhadap perputaran uang. Berbeda halnya dengan transaksi kartu kredit. 
- Transaksi kartu kredit berpengaruh positif dan signifikan secara statistik pada tingkat 0,05 (tingkat kepercayaan 95\%) terhadap tingkat suku bunga. Setiap kenaikan transaksi kartu kredit sebesar 1 juta akan meningkatkan tingkat suku bunga sebesar $0,00000023 \%$.

d. Pengaruh instrumen pembayaran non-tunai terhadap inflasi

- Transaksi e-money, transaksi kartu debet, dan transaksi kartu kredit tidak berpengaruh signifikan terhadap inflasi

e. Pengaruh instrumen pembayaran non-tunai terhadap stabilitas sistem keuangan

Pengaruh dilihat dari variabel independen yang berpengaruh signifikan terhadap variabel dependan. Pertama, transaksi e-money dan transaksi kartu debet berpengaruh positif terhadap jumlah uang beredar yang dapat meyebabkan inflasi dan mengganggu stabilitas moneter meskipun tidak secara langsung.

Kedua, transaksi e-money berpengaruh negatif terhadap tingkat suku bunga acuan sehingga dapat berpengaruh terhadap suku bunga tabungan dan suku bunga kredit. Untuk suku bunga tabungan, ketika suku bunga tabungan rendah maka masyarakat akan menggunakan uangnya untuk transaksi sehingga jumlah uang beredar meningkat dan dapat menyebabkan inflasi. Untuk suku bunga kredit, ketika suku bunga kredit rendah akibat kenaikan transaksi maka masyarakat akan melakukan kredit dan dapat berdampak terhadap stabilitas sistem keuangan apabila masyarakat tidak dapat melakukan pengembalian kredit.

Ketiga, transaksi kredit berpengaruh positif terhadap tingkat suku bunga karena semakin tinggi transaksi kredit yang dilakukan maka beban bunga atas transaksi tersebut yang dibebankan akan semakin tinggi, hal ini dapat memicu resiko default apabila nasabah lari dari tagihan dan menyebabkan ketidakstabilan sistem keuangan.

VI.2 Rekomendasi Kebijakan

- Seiring dengan meningkatnya transaksi instrumen pembayaran non-tunai, Bank Sentral perlu melakukan pengawasan lebih terhadap instrumen pembayaran nontunai agar pengaruhnya terhadap inflasi dan suku bunga dapat dikendalikan.

- Bank Sentral perlu mendorong stabilitas sistem keuangan melalui pengaturan dan pengawasan instrumen pembayaran non-tunai terhadap sistem keuangan

- Perlu adanya kebijakan dan pengaturan yang jelas tentang e-money dimana dalam penelitian ini e-money mempengaruhi M1 dan dapat dianggap sebagai komponen M1 agar kestabilan moneter dapat terjaga.

\section{DAFTAR PUSTAKA}

Artikel dalam jurnal: S, Lasondy Istanto dan Syarief Fauzie. Analisis Dampak Pembayaran Non Tunai terhadap Jumlah Uang Beredar di Indonesia Jurnal Ekonomi dan Keuangan Vol.2 No.10.

Artikel dalam jurnal: Syarifuddin, Ferry, dkk. 2009. Dampak Peningkatan Pembayaran Non-Tunai terhadap Perekonomian dan Implikasinya terhadap Pengendalian Moneter di Indonesia Buletin Ekonomi Moneter dan Perbankan April 2009.

Kertas diskusi (discussion paper series) Hidayati, Siti, dkk. 2006. Operasional EMoney. Kajian Bank Indonesia 
Kertas kerja (working papers): Pramono, Bambang, dkk. 2006. Dampak Pembayaran Non Tunai terhadap Perekonomian dan Kebijakan Moneter. Bank Indonesia Working Paper No. 11

Official website of Bank Indonesia (bi.go.id)

Peraturan Bank Indonesia Nomor 16/8/PBI/2014

Publikasi buku: Gujarati, Damodar N dan Dawn C.Porter. 2009. Basic Econometrics : Global Edition. Singapura: Mc Graw Hill.

Publikasi buku: Mishkin, Fredric S, 2013. The Economics of Money, Banking, and Financial Markets : Tenth Edition. England: Pearson Education, Inc.

Publikasi buku: Perry Warjiyo. 2016. Bauran Kebijakan Bank Sentral: Konsepsi Pokok dan Pengalaman Bank Indonesia. Jakarta:BI Institute

Publikasi buku: Reksoprayitno, Soediyono. 2000. Pengantar Ekonomi Makro : Edisi 6. Yogyakarta : BPFE-Yogyakarta.

Publikasi buku: Simorangkir, Iskandar. 2014. Pengantar Kebanksentralan: Teori dan Praktik di Indonesia. Bandung: Rajawali Pers. 